\title{
Employment Generation by Co-operatives: Myth or Reality?
}

\author{
Stephen Mago (PhD) \\ Great Zimbabwe University, P.O. Box 1235, Masvingo, Zimbabwe \\ E-mail: stepmago@gmail.com or stephen_mago@yahoo.com
}

Amos Mazise

University of Fort Hare, P. Bag X1314, Alice, 5700, South Africa

Costa Hofisi (PhD)

North-West University, Faculty of Commerce \& Administration, School of Management Sciences, Private Bag X2046, Mmabatho, 2735. South Africa E-mail: costa.hofisi@nwu.ac.za

\section{Doi:10.5901/mjss.2013.v4n3p753}

\begin{abstract}
This paper examines the role of small-scale producer cooperatives in reducing unemployment, providing income and food to rural people of Amathole in the Eastern Cape Province of South Africa. It is widely acclaimed that cooperatives have shown success in reducing unemployment. An examination was therefore necessary in the context of Amathole district, given rampant unemployment in this district. The paper relied on secondary data to establish the relationship between co-operatives and reduction of unemployment. Findings revealed that cooperatives employ worker-members and could not hire employees, managers and other skilled personnel. Income and food were other notable benefits. The paper recommends that the expansion and growth of cooperatives can be promoted through the provision of capital resources by the government. This will enhance cooperative employment creation efforts.
\end{abstract}

Keywords: Employment, co-operatives, producer co-operative, poverty reduction, South Africa

\section{Introduction}

Social and economic decline in many African countries is manifesting through high unemployment rates, hunger, and school dropouts in rural communities. These conditions have pushed people to seek economic activities as cooperatives to revive rural economies. This paper seeks to establish the role of producer co-operatives in reducing unemployment in Amathole District of the Eastern Cape Province in South Africa. Co-operatives are voluntary associations of persons united to meet their economic, social, cultural needs and aspiration (Dooren, 1978; Cloete, 1987; Birchall, 1994). Producer co-operatives are worker cooperatives which are either agricultural or non-agricultural. "The unemployed people refer to those who have not worked for more than one hour or during the short reference period but who are available for and actively seeking work" (ILO 2011:6). This study focused on job seekers defined as the unemployed, with reference to Amathole District of the Eastern Cape Province.

According to Woolord (2002) unemployment is closely linked to poverty in that countries with high rates of poverty are less industrialized and therefore less able to create employment. Poor people's living standards are low and so are the unemployed rural people in many cases. Cooperatives have had a stake in poor communities where they contribute to alleviation of unemployment and eventually to improvement of living standards (Woodlord, 2002 and Couture, 2009). Labor force participation is lower in poor than non-poor households and this applies to Amathole District where mining, the biggest employment provider in South Africa, does not exist.

The Eastern Cape Province is one of the nine provinces of South Africa. It stretches for 170616 square kilometers on the eastern side of South Africa (Binns, 1997). More than 60 per cent of its 6.8 million people live in rural homelands. The rural homelands refer to African ethnic reserves established under apartheid policies before 1994 (Binns, 1997). The province is the second largest and also second poorest after Limpopo province. Poor people in the province constitute 43 per cent as of 2006 and this is attributed to apartheid legacy of inequality and breaking down of family and community 
structure upon the migrant labour system from the homelands to work places in Johannesburg and other mining fields leaving women to take over home responsibilities (World Bank, 1995; Mazibuko and Vishwas, 2009). In certain districts up to 85 per cent of the economically active work force is unemployed (Development Bank of SA, 2004). This tendency has not yet improved in the Amathole District. Hence this study investigates the role of cooperatives in reducing unemployment in the rural areas of the district.

Binns (1994) and Stock (1995) share the view that economic development strategies in Africa need to focus on issues of local self-help and community self-reliance. Structural adjustment, droughts, welfare and the failure of top down strategies have forced a large proportion of African people to look inward to their own resources. Small scale producer cooperatives are ideal in putting the above focus into practice and at the same time cooperatives tend to provide employment to many people within their locality. Lack of employment in Amathole District formerly known as Transkei and Ciskei districts, is signaled by persistent poverty (Phillip 2003). Large scale agriculture Cooperatives featured in South Africa during the apartheid period but rural development remained elusive. The large scale agricultural cooperatives did not give the rural poor employment to improve their livelihoods; they were distanced from the majority of the people.

Small scale producer Cooperatives are worker co-operatives with membership playing the dual role of ownership and labour supply. Initiation is people driven, a characteristic favorable to rural development where it offers people opportunities to voice and make choice upon their priorities for their development (Chambers, 1983). Freedom to choose what to do create commitment to the co-operative task and the project is to the best interest of the members.

As development is a process which is participatory in nature (Chambers 1983, Davids and Theron, 2005), small scale producer cooperatives by virtue of their principles of member participation, autonomy and democracy among others become a vital strategy for reducing unemployment in Amathole District. It involves the beneficiaries in solving their own problems, taking the principle of bottom up to action in which those at the grassroots level make their voices and choices. According to Sen (1999) development entails expanding capabilities of the people to lead the kind of life they value and have reason to value. Small scale producer cooperatives are a development strategy that allows people to initiate what they need and manage for their development.

This study examined the role of small scale cooperatives in reducing unemployment in Amathole District as informed by the principles of co-operatives using the case of Hertzog Agricultural Cooperative, Seymour Development Forum, Zamukpilhila Women's Community Project, Philani and the Mpozolo Crafters project, which are examples of cooperatives existing in the district.

The Problem of unemployment is challenging human social endeavourers worldwide and it is worsened by decline of economies in many developing countries. South Africa, in which the Eastern Cape province is located suffers a high rate of about $27 \%$ unemployment, with rural unemployment as high as 49\%-52\% (Theron, 2008). Its district of Amathole is more affected and hope was put in the emergence of cooperatives. Cooperatives have been used in other countries as alternatives for solving the problem of unemployment. Cases in point include Germany, France, USA, India, and China (Dooren, 1978 and Delvetere, 2008). The question still remains whether small scale producer cooperatives can be used to supply jobs in the Eastern Cape Province, in particular, Amathole District. The objectives of this paper are to investigate whether small scale producer cooperatives can create employment in Amathole and to establish whether co-operatives can provide income and lessen food scarcity among the rural people of Amathole.

Significance of this study lies in its attempt to establish the significance of cooperatives and possibly laying the basis for necessary innovations to policies regulating cooperatives. Optimists see South Africa resorting to self-help remedies (Delvetere et al, 2008) such as cooperatives in efforts to create employment. As there is not much information serving as feedback to the government on creation of employment by cooperatives, this article may serve that purpose.

The choice of Amathole has been purposefully made on the rationale that Amathole is in the Eastern Cape which has the second highest number of cooperatives constituting about 33\%. It is the second poorest province with rural unemployment in the range of 49\%-52\% (Theron, 2008). The cooperatives examined were Hertzog, Zamukhuphila, Seymour Development Forum, Philani and Mpozolo.

\subsection{Cooperatives and Employment Creation}

The International Cooperative Alliance (ICA) (2005) defines the term cooperative as an autonomous association of persons united voluntarily to meet their common economic, social and cultural needs and aspirations through a jointly owned and democratically controlled enterprise. The main focus in the definition is on freedom and democracy in pursuance of group objectives. Cooperative members are free to join and to secede from the cooperative. There is 
consensus in decision making which countervails exploitation, dominance by leaders or others and stimulates members' commitment.

There is an assumption that leadership is based on consensus to isolate potential dominance, those selected to be the cooperative committee do not make decisions but consult the members to reach an agreement. However, there is a thin line of reality in trying to avoid the existence of politics in cooperatives. Top-down and bottom-up management are both subject to leadership problems, though of varying intensity.

Empirically, cooperatives emerged in Western Europe and in parts of the United States of America (U.S.A.) and Australia in the seventeenth century to allow small producers to assert their independence more effectively, contributing significantly to progression from subsistence to market economy. Between 1914 and 1950, five categories of cooperatives emerged: the consumer cooperative pioneered by Rochdale of England, worker cooperative in France, credit cooperative in Germany, the agricultural cooperative in Denmark and Germany and housing cooperatives emerged in parts of industrialised Europe (Dooren, 1978).

In Eastern Europe (Russia) cooperatives began after the Second World War as socialist collective production under central authority planning. The perspective of cooperatives in Europe and USA was underpinned by the ideology of economic growth. While in Africa it was influenced by colonialism whose masters wanted to increase food production for their industrial workers (Dooren, 1978 and Delvetere, 2008). Focus was on large scale farmers which have recently been realised to be ineffective in rural development (Binns, 1997; Erasmus, 1994).

The current narrative apprehends small scale cooperatives as relative (Mayson, 2004 and Ortmann, 2007) and has gained South African government support through policy reviews in 2002. The policy defines that government expects improved conditions for cooperatives' registration and capital structure to facilitate job creation and economic development by cooperatives. The government of South Africa anticipates a positive correlation between cooperatives and reduction of unemployment. It reveals this notion in the cooperative act (No. 14 of 2005) in which it expresses the obligation of cooperatives as to create employment and generate income (Ortmann and King, 2007).

\subsection{Principles of Cooperatives}

The International Cooperative Association charters principles that guide the operation of cooperatives (International Cooperative Association, 2005). These are rules which defray obstacles in cooperative organisation. Joining a cooperative is voluntary and open to willing members of that community while seceding the cooperative is free. The organisation is controlled by the members democratically. The assumption is all members possess equal powers to determine the operation of the cooperative but practically this may cause drawbacks on efficiency where every decision has to be approved by all members. To the contrary, more often, the better skilled tend to dominate in decision making without approval from the group members.

Cooperatives are autonomous organisations; they are not controlled by external authorities, they are self-initiated and self-reliant and this is substantiated by members' contributions at the beginning which saves as share capital. The organisation offers its members education and training for effective performance, especially, new office bearers. Above all, cooperatives work in close association with other cooperatives; creating cooperative unions which are advantageous in bargaining at higher levels (Phillip, 2003; Delvetere, 2008; Couture, 2002 and Dooren, 1978). Unions represent matters concerning the welfare of cooperatives such as policies governing cooperatives at lower levels to the government through the Department of Trade and Industry.

\subsection{Types of Cooperatives}

Two main features differentiate user-cooperative from worker-cooperative, in user cooperatives members are not workers of the cooperative and do not take the cooperative as the only source of livelihood. Where as in producer cooperatives which fall under worker cooperatives, members have dual characteristics. They are members and workers. Members of small scale cooperatives remain independent but pledge themselves by contracts to supply specified produce. The members work together on those individual plots. The smallness of the cooperative is assumed to facilitate increased participation, satisfaction and quick turns of hosting member service delivery as well as increasing creation of more cooperatives in a community enhancing involvement of more unemployed people in employment.

Produce-Marketing Cooperatives deter middlemen and offer opportunities for maximising profits at direct sales. Middlemen and local dealers often deprive producers of potential profits through lower payments for their produce. However, some cooperative members still fall prey to village dealers when they need money earlier than the cooperative 
marketing time despite the cooperative principles which require members' approval of any decision (Dooren, 1976).

Cooperative Processing is usually an expansion of marketing cooperatives that reduces opportunistic exploitation from dealers, processors and the middlemen. Dooren (1976) argues that cooperative processing is essential for increasing rural income and credit for production. Members also gain the added value from their processed produce but many rural people find it daunting to engage in processing cooperatives which demand technological resources. This results in scarce processing cooperatives in rural areas to save perishables during unviable markets. Other cooperatives are the credit, consumer, and housing and industrial worker cooperatives. All are vital in rural development although agricultural cooperatives tend to be more readily accepted.

\subsection{Cooperatives and Unemployment}

According to rule 193 on promotion of cooperatives recommendation of 2002, globally cooperatives are expected to offer employment and income to people (ILO 2002) and this concurs with the argument of Theron (2005); Abrahamsen (1978) and Dooren (1976) that cooperatives increase rural income and employment. Provision of employment to rural people serves a number of livelihoods. Adequate income enables members to afford descent food, clothing, and school fees for their children and other necessities.

There are conflicting ideas as to the definition of unemployment. Kingdon and Knight (2001) noted that on one hand unemployment is regarded as voluntary, on the other hand it is treated as involuntary. The argument for the voluntary perspective is that if the unemployed are in need of employment they should either get it from the informal sector or from the formal sector. The involuntary perspective cites limited opportunities for the unemployed to join the formal sector and that there is lack of capital for self-employment in the informal sector.

These debates above are provoked by the unemployment situation in South Africa. The country has been experiencing increasing unemployment since 1995 from an inclusive rate of 39 per cent to an exclusive rate of 26 per cent (Kingdon and Knight, 2001 and Leat, 2006). The inclusive percentage includes those who are unemployed but not actively searching for the employment. The crux of the matter is on the effect of unemployment on rural people of Amathole District regardless of how it occurs. Kingdon and Knight (2001) and Mlatsheni (2002) cited negatives of unemployment as melting down human capital. The unemployed active labour migrates in search of jobs causing brain drain. Cooperatives could turn the brain drain into brain gain in rural areas.

Social instability is ensued by unemployment, people engage in antisocial endeavors such as theft for survival. Unemployment also causes social exclusion to the jobless people. Lack of employment defines their minimum chances to access income and therefore deter them from active participation in social activities such as education, sports and health. Above all it affects the rural economy of the homeland people through loss of the economically active people leaving for places with employment.

Unemployment affects rural people's livelihoods. Horn (2000) defines livelihoods as means of earning sustainable living exemplified by working, growing vegetables, vending and fishing among others. This entails that cooperatives are enterprises that offer employment with which rural people earn income to meet their needs and other means to some social, economic and cultural ends.

\subsection{Theoretical proposition}

This study is underpinned by the theory of participatory development which is viewed by a number of authorities as a recent approach to rural development capable involving and empowering the beneficiaries. According to De Beer and Swanepoel (1998); Chambers (1983); and Kotze \& Kellermen (1997), participatory theory explains an approach which is people-centered. Participation of people is indispensable because development is for the people and should be by the people themselves, which is the central principle of cooperatives to make participants the initiators of their self-help enterprises based on choice and common interest. In this case it implies creation of employment by the unemployed themselves through cooperative initiatives.

In the context of participatory development, Participatory Rural Appraisal (PRA) is at one level seen as a reaction to the Neo liberal market theory that concerns extraction of profits without emphasis on empowerment of the poor and sustainability of the initiatives imposed on the people. This made such approaches to rural development, top-down and from the outsiders with the goal to benefit from the rural poor people (Chambers, 1994 and Hill, 1997). The debate for Participatory Rural Appraisal is based on redressing the failure of the previous programs informed by outsiders' initiatives to make programs reach the poor, particularly those living in remote rural areas (Easter, 1995). 
Themes in participatory theory akin to cooperative principles and values entail conceptualisation of the cooperative project by members and agreed to by the members. The project has to be a product of shared decision; joined willingly predicating democracy (Leat 2006; Ortmann and King 2007). Implementation of the selected project is through members' participation or approval. Members all take part in monitoring and evaluating the project either by actively taking the exercise or by endorsing the agreement on monitoring criteria. Participation of members extends to decision making on disbursement of proceeds to ensure equal and equitable benefits to all members (Theron 2005 and Oyedemi 2009).

Notwithstanding the participatory incentives, procedures turn out to favour co-option of the interests of the powerful and application sometimes suffers from manipulation and tokenism (Cornwall 1995). This violation of the principle and values of cooperatives, affect the progress of cooperatives and sometimes affect members to abandon cooperatives. It entails that cooperatives have to abide by the cooperative principles for success. In other countries cooperatives have made a dent in improving the lives of individual's especially when governments gave support interventions with minimum interference. The Hope Tien Agricultural Cooperative of Vietinam and Rooibos Tea Cooperative of South Africa made remarkable success (Theron 2009).

\subsection{The Profile of Amathole District}

Amathole District Municipality is in the Eastern Cape Province of South Africa. There is Cacadu to its South, Chris Hani to the North and Oliver Tambo to the North East. The Town of East London lies along its coastal border to the east. The western side of the district is considerably dryer, with less than $500 \mathrm{~mm}$ per annum, than the Eastern side, which has rainfall as high as $1000 \mathrm{~mm}$ per annum along the coast (Zenzile 2007). It has the largest population in the Eastern Cape. It accounts for more than $26 \%$ of the provincial population. Two thirds of the district is made up of ex-homeland areas, which are largely rural by nature. The Amathole district is poor, with about $67 \%$ of its people living in poverty (The Mayor 2009).

\subsection{Employment and Unemployment}

The level of unemployment in Amathole follows national and provincial trends. The national trends show fluctuations between 23 and 25 percent. Statistics South Africa (StasSa)'s Quartely Labour Force Survey of Quarter 4, 2012 shows that unemployment has been on the increase. For example, the rate of unemployment was 23.9 percent during the October-Decemeber 2011 period and it slightly reduced to 24.9 percent in October-December 2012. Currently, it is estimated at 25.5 per cent. For the Amathole district municipality, the trend follows the same story-line. In 2003, the number of the unemployed looking for work was estimated to be $23 \%$, whereas those not working and not looking for work constituted about $25 \%$. Those not working for other reasons totaled another $14 \%$. The average unemployment count in 2003 in Amathole was about 62\%. The percentage of unemployment comprises more of rural residents, who could not be employed by the few available industries. The industrial sector is dominated by the manufacturing business in the automotive industry of East London, and food processing and textile departments (Mayor 2008).

The industries only managed to employ $25 \%$ in the year 2000 . This indicates that the rest of the job seekers did not have employment. Amathole District Municipality has the largest economy in the Eastern Cape and its manufacturing sectors contribute the highest to the provincial GDP, (In 2000, it contributed $21 \%$ to value added of $27 \%$ ) while agriculture contributed $3,6 \%$. Since the agricultural sector mostly dominated by the rural people is not performing well, it implies that an increase in employment needs to take up the slack in the provision of livelihoods. Small-scale producer cooperatives are a strategy that can feel the gap by employing the rural people.

\subsection{Methodology, data presentation and analysis of findings}

This section outlines the research design. The section presents how the secondary data were collected for use in this study. Data were collected between May and October 2011 from secondary sources. According to Lehmaron (1989), Parasuman (1986) and Mark (2004) secondary data are the data that have been collected from respondents, for purposes other than the research at hand. Data collected were about small scale producer cooperatives and unemployment in Eastern Cape Province. A convenience sample of five cooperatives was extracted from cooperatives of Amathole District on the basis of their appearance in pre-collected data accessed on internet, journals, government documents and text books. According to Gray (2004) convenience sampling selects subjects on the basis that the subjects are conveniently available. However, it needs to be treated with caution as it may leave out important characters 
in this case, cooperatives. Units of analysis are objects that are observed to draw an explanation (Rosenberg, 1968; Babbie, 2004). As units of analysis include organisations and their roles, it entails that cooperatives fitted well to be observed as units of analysis.

The choice of the five cooperatives; Hertzog, Zamukhuphila Women's Community Projects, Semyour Development Forum, Philani and Mpozolo Weaving Project whose data were available on internet and in documents is believed to be suitably representative of rural cooperatives in Amathole District. Collected data were presented using both quantitative and qualitative methods. Quantitative methods represent data numerically while qualitative methods use implicit descriptions (Gray 2004; Babbie 2008). Data analysis involves the process of breaking data down into smaller units to reveal their characteristics, elements and structure (Babbie, 2004; Gray, 2004). The discussion of findings applied qualitative methods only because the pre-collected data did not comprise much of numerical information especially on values of income.

\section{Findings of the study}

\subsection{Government's Position about Unemployment and cooperatives}

The South African government embarked on the expanded public works programme (EPWP) to expand government generated employment opportunities for people who are marginalised and unemployed. It intended to create one million jobs in cooperatives over 5 years through the establishment of self-help groups and facilitation of access to micro-credit (Neves, 2007). The programme was an attempt to concretise Black Economic Empowerment (BEE) in South Africa. The black empowerment ideology in the post-apartheid era was meant to balance economic opportunities for all, especially, the South African victims of apartheid disparities. According to Theron (2008), cooperatives increased in number, since 1994, in response to BEE and unemployment as shown by the table below. This tendency explains the need for employment by the job seekers.

Table 1. Growth of cooperatives between 1994 and 2005

\begin{tabular}{|c|c|c|c|c|}
\hline Year & $\begin{array}{c}\text { Agricultural } \\
\text { cooperatives }\end{array}$ & $\begin{array}{c}\text { Trading } \\
\text { cooperatives }\end{array}$ & Total & $\begin{array}{c}\text { Percentage } \\
\text { increase }\end{array}$ \\
\hline 1994 & 256 & 213 & 469 & \\
\hline 2004 & 307 & 2150 & 2457 & 423.9 \\
\hline 2005 & 708 & 4316 & 5024 & 104.5 \\
\hline
\end{tabular}

Source: Theron 2008.

The table illustrates the rise of cooperatives noted soon after the end of the apartheid era in 1994. Theron (2008) posits that to appreciate the employment potential of cooperatives, one must first of all acknowledge the dramatic decline of formal employment opportunities in the South African economy since the 1970s. Informal sector employment complements the formal sector employment. The International Labour Organisation (2000) defines informal sector employment as comprising all jobs in the informal sector enterprise or all persons who during the given reference period were employed in at least one informal enterprise, The assertion affirms that informal sectors are offering jobs which people may not recognise as employment despite their massive contribution to employment.

The Cooperative of Hertzog lies along the Kate Valley in the Amathole District. It was launched in 1994 by 1000 small scale farmers who shared a piece of land into individual farming units. The success of the project was based on good local leadership and resourcefulness of the committee. The project started with a loan obtained from a commercial bank (Binns, 1997; 2000). The cooperative produced 8000 heads of cabbages each per plot holder and the income of members quadrupled monthly. The quality of members' life improved remarkably.

Zamukhuphila Women Community Project consists of 13 women living in Upsher Village close to the town of Balfour. The objectives of the cooperative were to establish a community vegetable project that would give them a source of income and food to improve the nutrition of their children. An established commercial farmer, their neighbour used to assist them with irrigation (Nel and Binns, 2000). The cooperative employed 13 worker members and provided valuable household food budgets. The cooperative produced cabbages, carrots, beetroots potatoes and spinach. The selling of these products generated supplement household income.

Seymour Development Forum lies on the banks of the Kate River in the former Ciskei homeland. It was 
established in 1992 following the downfall of the Ciskeian regime to restore the economy and create employment. It had a high degree of external support from the Corplan, a community based non-governmental organisation which assisted with funding and training. The cooperative embarked on a community garden initiated by 60 people and several hundreds of people got employment in different projects revived as cooperatives (Nel and Binns 2000). The challenge of the cooperative was surviving largely on donor support.

Philani Cooperative began in 1994. It is located in Balfour and employs 300 worker members. The project was registered as a nonprofit organization. Its priorities were skills training, vegetable production, bead making and tourism business. It acquired a loan of R30 000 from the Eastern Cape Development Agency for seed potatoes, training members in sewing, leather work, fence and bead making. It also acquired R50 00 for restoration of the tourist centre and a local Museum managed by 24 members (Eastern Province Herald, 1997). At the time the data was collected, few jobs were on offer apart from that of worker members of 300 people (Binns 1997).

Mpozolo Crafting Cooperative has been in existence for centuries but cooperating and commercialising the artifacts started in 1996 (Taryn et al 2006). The objective of the cooperative was to earn income from the project. The Mpozolo crafters had 40 members. They made baskets, brooms and ropes from Cyperus textilitis and jucus Kraussi reeds harvested from nearby farms. The products are sold in the villages and towns of King Williams and East London. They were helped by REHAB, a non-governmental organization who bought and sold their artifacts. Selling mats, brooms, basket and ropes earn the members income for livelihoods.

Table 1. Cooperative employees

\begin{tabular}{|c|c|}
\hline Cooperative & Worker Members \\
\hline Hertzog & 1000 \\
\hline Zamukhuphila & 13 \\
\hline Seymour & 60 \\
\hline Philani & 300 \\
\hline Mpozolo & 40 \\
\hline Totals & 1413 \\
\hline
\end{tabular}

Source: Author's compilation (2010).

\subsection{Employment}

The above table indicates the number and type of employees that the five cooperatives in Amathole District employed. The cooperative owners did not employ managers and hire labour as found with other cooperatives like Rooibos cooperative in the Western Cape Province, cooperatives in Europe, United States of America and Kerala state in India. They managed the cooperatives themselves through their leadership of chairpersons and committee members.

\section{Discussion of Research Findings}

\subsection{Unemployment}

The five cooperatives: Hertzog, Zamukhuphila, Seymour Development Forum, Philani and Mpozolo demonstrated employment creation capabilities for worker members. Table 1.1 portrays a total number of 1413 people employed as worker-members in Amathole District. The act of creation of employment by the five cooperatives tallies with the experiences of cooperatives in other studied cooperatives of Kerala of India (Phillip, 2003), Hope Tien Agricultural Cooperative (Couture et al, 2002), Xiangchung Supply and Markerting Cooperative (Shen Tai-ji and Zhan Wangu-Shu, 2002) and Rooibos Tea Cooperative (Theron 2005).

However, distribution of employment among the villages and the cooperatives was uneven, as illustrated in Table 1.1. Hertzog has $89.8 \%(1000)$ of the total employees while Zamukhuphila cooperative with the list employees has 1 , $2 \%$. Unemployment resulted in social discrimination of the jobless. In some cases, it causes the unemployed to indulge in antisocial behaviour such as theft (Knight and Kingdon 2001). They concur with Mthembu Ntokozo (2005) who acknowledges labels of the unemployed as community defenders, criminals and rapists. Therefore, uneven distribution of cooperatives and employment in the communities cause such problems to haunt societies. Cooperatives' growth is not well pronounced in Amathole since there were no details found on membership increase and on replication of the same project in other surrounding villages as the trend with cooperatives such as the Rochdale Cooperative of England 
(Dooren, 1978). Replication of same projects in other communities indicates growing or overgrowing of the initial enterprise like what happened to Kerala of India and Hope Tien of Vietnam (Phillip 2003; Couture 2002). This seems not to be happening with the cooperatives of Amathole District. It might imply that the cooperatives are facing growth challenges and need intervention from well-wishers.

\subsection{Cooperatives}

Experience from the European cooperatives and even from the Rooibos in the Western Cape Province pointed out that self-sustained, member controlled cooperatives survived and grew large (Theron 2008). Observation of the secondary data revealed that the Seymour cooperative relied on money donated by the government for reviving factories left by White settlers. On the other hand Zamukhuphila relied on a neighbour commercial farmer for tilling their land. According to the cooperative principles, dependence kills autonomy, independence, member control over their project and opens the project to elite capture. These cooperatives did not witness problems emanating from the above view, which can mean that cooperatives in Amathole District of Eastern Cape do better with support from outsiders.

There is evidence from cooperatives in Vietnam, Xiangcheng and Kerala that employing managers is indispensable for the efficiency of cooperatives (Couture 2002). The same condition should apply for cooperatives in Amathole District. They can improve performance of their cooperatives by employing managers to direct the activities of their enterprises in a more skillful and productive manner. Besides direct benefits to members, employing managers add to the purpose of their existence as purview of the government of South Africa (Theron 2008, ILO 2002). Lack of managers could be stifling the growth of cooperatives in Amathole District.

\subsection{Other Benefits From Cooperative Employment}

This study established that small scale producer cooperatives serve as sources of food and income. Zamukhuphila made production of nutritional food for their children. The successful production of a variety of vegetables such as cabbages, spinach, carrots, onions, potatoes and tomatoes implied the cooperative worker members would also get some vegetables for their consumption apart from employment. Amathole cooperatives benefit worker-members with food at low costs and also income which is synonymous with the practice of the Hope Tien Agricultural cooperative of Vietnam (Couture 2002). In all cases, collected secondary data revealed that the cooperative members earned some income with Hertzog project members confirming receiving quadrupled income monthly (Binns 1997; Nel 2000). Notwithstanding this positive indication secondary data collected for this study fell short to implicitly give the quadrupled figures of the income but evidence of income source creation by cooperatives was envisaged in small scale cooperatives.

\subsection{Cooperative Growth/Challenges}

Records indicate cooperative growth in South Africa from the period of the demise of apartheid in 1994. Lack of update information on cooperative performance and registration as noted by Theron (2008) discredited the department of Trade and Industry. It should compile records that point to the performance of cooperatives as a feed back to the government that entrusts cooperatives with creating informal employment.

Evidence from Table 2 portrays cooperatives were growing recognizably and supplying annual reports to the Department of trade and industry between 1994 and 2005. Growth of cooperatives during the period confirms value attached to cooperatives as a supplementary source of employment by the government. Income and food for cooperative members have been noted as other benefits from cooperative employment.

\section{Summary and Conclusion}

The main aim of this study was to investigate whether small scale producer cooperatives reduce rural unemployment in Amathole District in South Africa. A convenience sample of five small scale producer cooperatives was drawn on the basis of their existence and availability of data about them in secondary sources. Analytical survey was used to gather pre-collected data. The data was accessed on internet, from journals, government documents and text books.

The problem of unemployment at the rate of 26 per cent by the definition of unemployment of those looking for it and 39 per cent by the definition of unemployment which includes those looking for it and the discouraged job seekers, prompted this study. It sought to establish whether small scale producer cooperatives reduce unemployment, serve as 
sources of food and income in rural areas, particularly in Amathole District. Findings indicated that in this district, small scale producer cooperatives provide employment to 1413 people who are worker -members and that the cooperatives fell short of employing managers as happening to cooperatives in other countries. This could be due to the fact that most of the cooperatives are small and manageable without them and that the cooperative members could not afford the salaries which managers would need despite their importance to the cooperatives' efficiency. However, the five cooperatives have some similar traits observed on cooperatives in Europe, USA, India and Western Province of South Africa of providing members with employment, income and other scales of economy (Couture, 2002; Delvetere, 2008; Theron, 2005 and Phillip, 2003).

The study has confirmed the assumption of the government that cooperatives as self-help projects create employment for the rural job seekers. What seemed to have been unknown to the proponents of the premise is the magnitude of the employment capacity and typology of employees which this study to some extent unveiled. Small scale producer cooperatives proved capable to provide employment to worker members through their participation. In this research, 1413 worker members were employed by the five cooperatives and none of the cooperatives employed managers and other non-members of the cooperatives. Employment of managers and other non-members of the cooperatives depends on sizes, efficiency and viability of the enterprises. Since the projects considered in this study were small scale, it could be the reason why they did not have hired labour. Implicitly, small producer cooperatives provide employment, income and some food to worker members. However, there might be need for the provisions to be increased by improving the sizes, and resources of the cooperatives.

\section{Recommendations}

In view of the strengths and challenges of cooperatives noted in this study, the fight against unemployment with cooperatives as instruments require much field research on the performance of cooperatives to establish government support policies on size, capital resources and employment capacities. Lack of statistical updates on employment creation with cooperatives makes judging employment with cooperatives as neither fiction nor reality. Cooperatives should widen their employment base by employing non-members of the cooperatives and managers like other cooperatives in Vietnam, India, Europe and USA which they are emulating. It also makes them efficient thereby creating more employment opportunities. Recommended field research may assist the Department of Trade and Industry (DTI) of South Africa to take stock of functioning cooperatives, the number of employees in cooperatives and to assist in establishing more throughout the communities of the Eastern Cape Province.

\section{References}

Abrahamsen, M. A. 1976. Co-operative Business Enterprise. USA. McGraw-Hall.

Ashley, C. Maxwell, S. 2001. "Rethinking Rural Development", Policy Review, 19 (4): 395-425.

Babbie, E. 2008. Introduction to Social Research. Fifth edition, USA: Wadsworth.

Binns, T. 2000. "Rural Self-reliance Strategies in South Africa": Community initiatives and external support in the former black homelands, 16 (2000): 367-377.

Birchall, J. 2005. "Cooperative Principles Ten Years On."International Cooperative. Alliance, Issue 2, 98(2):45-63.

Bond, P. 2001. The IMF and WB Reconsidered. In Coetzee, J.K. and Graaff, J. (eds). Development theory, policy and practice. Cape Town: Oxford University Press.

Bonnin, J.P. 1984. "Membership and Employment in an Egalitarian Cooperative."Economica New Series, Vol. 51, (203): 295-305. London: Blackwell Publishing.

Bottomely, T. 1987. An Introduction to Co-operatives: A Learning Program Text. London: Intermediate Technology Publication Ltd. Chambers, R. 1983. Rural Development: Putting the last first. U.S.A.: Longman.

Chisi, R. Madziyire NC, Mhlanga E, Kwandayi HP, Makombe B 2004. Research Project Guide. Zimbabwe: ZOU.

Cloete, G. R. 1987. "Co-operative and Rural Development": Development Southern Africa, 4: (3): 543-552.

Cornwall, A. 1995. Department of Anthropology and Sociology School of Oriental and African Studies. London: University of London.

Couture, D. Faber, M. Nipppierd, L (eds) 2002.Transition to cooperatives Entrepreneurship. Geneva: international Labour Office.

Davids, I. Theron F., Maphunye J.K. 2005. ParticipatoryDevelopment in South Africa:A Development Management Perspective. Pretoria: Van Schaik Publishers.

DeBeer, F. Swanepoel H 1998. Community Development and Beyond: Issues, Structures and Procedures. Pretoria: Van Schaik.

Delvetere, P. Pollet, I., Wanyama, F (eds) 2008. Cooperating out of poverty: the renaissance of the African cooperative movement. Geneva: International Labour Office, World Bank Institute.

Duncan, K. 2008. "An investigation of changing socio-economic conditions, opportunities and small Eastern Cape Towns in South Africa." Master's thesis, Rhodes University. 
Fields, G. S. 2000. The Employment Problem in South Africa. Keynote address Prepared for Presentation at the Trade and Industrial Policy Secretariat Forum on "Paths to Growth and Employment in South Africa," Johannesburg, South Africa: Cornell University.

Gomm, R. 2008. Social Research Methodology: A critical Introduction. Second edition. New York: Palgrave.

Gray, E. D. 2004. Doing Research in the Real World. London: SAGE Publication Ltd.

Horn, J. 2000. Instrument for Sustainable Private Sector Forestry. South Africa

Huysamen, G. K. 1984. Methodology for the Social and Behavioural Sciences. South Africa: ITP.

Hussmanns, R. 2004. "Measuring the Informal economy: From employment in informal sector to informal employment." Working Paper No. 53. Geneva: International Labour Office

International Labour Organisation. 2011. An Introductory Guide for Employers' Organizations : Tackling Youth Employment Challenges An overview of possible actions and policy considerations. International Training Centre of the ILO, Turin, Italy.

Knight, R. 2006. "Challenges for Future Delegation." Briefing Paper 11/06.

Broadbent KP 1990. "Information needs for Rural Development," Information Development, 6(1):49-54.

Leat, A. 2006. "Income Poverty in South Africa." South Africa Child Gauge.

Mazibuko, K and Jangara V. 2008. Eastern Cape socio-economic consultative council: Working paper series No. 5; International Cooperative Experience and Lessons for the Eastern Cape Cooperative Development Strategy: A Literature Review. Cooperative and Policy Centre.

Mlatsheni, C. and Sandrine, R. 2002. "Why is Youth Unemployment so High and unequally spread in South Africa?" Development Policy Research Unit Working Paper 02/ 65. South Africa: University of Cape Town.

Neves, D. 2007."In search of South Africa's Second Economy: Chronic Poverty, Economic Margininalisation and Adverse Incorporation in Mount Frere and Khayelitsha." South Africa: University of the Western Cape.

Ortmann, G.F. and King, R.P., 2007. "Agricultural Cooperatives 1: History, Theory and Problems." Agrekon, 46: (1), 18-46.

Phillip, K. 2003. "Co-operatives in Southern Africa: Their Role in Job Creation and Poverty Reduction," for the South African Foundation.

Oakeshott, R. 1990. The case for Worker`s Co-operatives. London: MacMillan Press Ltd.

Sapsford, R and Jupp, V. (eds) 2006. Data Collection and Analysis. Second edition. London: SAGE Publication.

Republic of South Africa.2005 b. Cooperatives Act, 2005. Government Gazette, 18 August 2005, Cape Town, South Africa

Sagent, M. 1982. Agricultural Cooperation. England: Gower Publishing Company Limited.

Shackleyon, T; and Shackleton, C. 2006. "Trade in reed-based craft products in rural villages in the Eastern Cape, South Africa", Development Southern Africa, 23: 4, 477-495.

Theron, J. 2005. The cooperative tradition in South Africa and Namibia. Essential Research for a cooperative facility. In Develtere, Patrick (et al), (eds). 2008. Cooperating out of poverty. The renaissance of African cooperative movement. Geneva: ILO.

Van Dooren Pierre, J. 1978. Co-operatives for Developing Countries: Objectives, Policies and Practice. Countinho: Muiderberg.

Zenzile, M. L. 2007. "A study of the Amatole District Municipality's Settlement plan in the light of the reform and spatial planning measures; South Africa." Master's thesis, Rhodes University.

Statistics South Africa (StatsSa) 2012. Quarterly Labour Force Survey. South Africa. Pretoria. http://www.statssa.gov.za /publications/P0211/P02114thQuarter2012.pdf 